\title{
Er zit meer achter het etiket
}

Citation for published version (APA):

Sijm, D. (2019). Er zit meer achter het etiket. Maastricht University. https://doi.org/10.26481/spe.20191115ds

Document status and date:

Published: 15/11/2019

DOI:

10.26481/spe.20191115ds

Document Version:

Publisher's PDF, also known as Version of record

\section{Please check the document version of this publication:}

- A submitted manuscript is the version of the article upon submission and before peer-review. There can be important differences between the submitted version and the official published version of record.

People interested in the research are advised to contact the author for the final version of the publication, or visit the DOI to the publisher's website.

- The final author version and the galley proof are versions of the publication after peer review.

- The final published version features the final layout of the paper including the volume, issue and page numbers.

Link to publication

\footnotetext{
General rights rights.

- You may freely distribute the URL identifying the publication in the public portal. please follow below link for the End User Agreement:

www.umlib.nl/taverne-license

Take down policy

If you believe that this document breaches copyright please contact us at:

repository@maastrichtuniversity.nl

providing details and we will investigate your claim.
}

Copyright and moral rights for the publications made accessible in the public portal are retained by the authors and/or other copyright owners and it is a condition of accessing publications that users recognise and abide by the legal requirements associated with these

- Users may download and print one copy of any publication from the public portal for the purpose of private study or research.

- You may not further distribute the material or use it for any profit-making activity or commercial gain

If the publication is distributed under the terms of Article $25 \mathrm{fa}$ of the Dutch Copyright Act, indicated by the "Taverne" license above, 
Prof. Dr. Dick T.H.M. Sijm

Faculty of Science and Engineering

\section{Er zit meer achter het etiket}




\section{Iergie witten solhydraten waarvan suikers tten vaarvan verzadigd vet enkelv. onverz. vet meerv. onverz. vet jedingsvezel atrium}

OOEDINGSWAARDE PER 1 C

\section{Er zit meer achter} het etiket

Oratie prof. dr. Dick T.H.M. Sijm

Leerstoel

"Voedselveiligheid in een duurzame economie" Universiteit Maastricht

15 november 2019 


\section{ER ZIT MEER ACHTER HET ETIKET}

Oratie uitgesproken bij aanvaarding van de leerstoel "Voedselveiligheid in een duurzame economie", op 15 november 2019.

Geachte prof. dr. Cleij, decaan van de Faculty of Science and Engineering en pro-rector, collega's, familie en vrienden, dank voor uw aanwezigheid en belangstelling. Het is $\mathrm{mij}$ een grote eer mijn inaugurele rede vandaag voor $\mathrm{u}$ te mogen uitspreken en hierbij het ambt van hoogleraar te aanvaarden.

Vanmiddag vertel ik $u$ wat ik met mijn leerstoel wil bereiken. Ik neem u mee op mijn eerste schreden in het wetenschappelijk onderzoek en start met het vertellen hoe mijn vroegere opleiding een basis heeft gevormd voor mijn onderzoek naar voedselveiligheid. Ook zal ik kort iets over de duurzame economie uitwijden. Uiteraard zal ik ook de titel van mijn oratie nog nader toelichten.

\section{Mijn eerste schreden in het} wetenschappelijk onderzoek Ik ben opgeleid aan de Universiteit van Amsterdam in de milieuchemie. De eerste milieuchemicus waarmee ik in aanraking kwam was prof. Otto Hutzinger (zie: Hutzinger). Hij verzorgde een college milieuchemie en deed dat op zijn eigen typische manier: door veelal net op tijd de collegezaal binnen te komen, snel een serie dia's klaar te zetten en dan een geweldig verhaal te vertellen over een milieuprobleem, vanuit het perspectief van een wetenschapper. Hij heeft me enorm geïnspireerd en bracht me met zijn vele verhalen in aanraking met de interessante facetten van het milieuchemisch onderzoek. Antoon Opperhuizen, toen nog geen hoogleraar, nam het stokje over en heeft me vervolgens enthousiast gemaakt om een promotie-onderzoek te gaan doen.

\section{Stapeling in de voedselketen}

Een van die verhalen gaat over de ijsbeer. Ik neem u nu dus mee naar de Noordpool in de jaren '70 en ' 80 van de vorige eeuw. Wetenschappers ontdekten dat ijsberen hoge gehalten aan PCB's in hun vet hadden, tot wel $20 \mathrm{mg} / \mathrm{kg}$ in hun vetweefsel (Bernhoft et al., 1997). Dat was een hele merkwaardige bevinding, want die PCB's werden op de Noordpool zo goed als niet gebruikt. De milieuchemische vragen waren:
- Hoe komen die PCB's daar en

- hoe kunnen zulke hoge concentraties in de ijsbeer komen?

Ik heb in het jaar 2000 eens uitgerekend dat een ijsbeer meer dan 10 miljoen liter zeewater per dag had moeten drinken om die PCB's uit de oceaan te halen (Sijm, 2000) en dat is natuurlijk niet realistisch. Ook het scenario dat de ijsbeer die PCB's uit de lucht zou inademen, dat vele miljoenen kubieke meters lucht per dag zou betekenen, is ook niet realistisch. Wat overblijft is dus dat de ijsbeer die PCB's uit het voedsel opneemt.

Die hoge gehalten aan PCB's - en vergelijkbare verbindingen - leidde tot ongewenste effecten bij de ijsbeer, zoals gewijzigde concentraties van hormonen (cortisol) en vitamines ( $A, E$ en $D$ ), effecten op de lever, nier, en thymus en effecten op het afweersysteem, het zenuwstelsel, de botten en zelfs tot het ontwikkelen van een ogenschijnlijke penis bij een vrouwtjes ijsbeer (Sonne, 2010).

Wat nodig was voor die ijsbeer, was dus veilig voedsel, zonder nadelige effecten van PCB's of andere chemische stoffen. Die wens voor veilig voedsel heb ik ook en geldt dus voor de ijsbeer en de mens.

\section{Hoge concentraties in de ijsbeer}

Ik beantwoord eerst de vraag hoe die hoge concentraties PCB's in de ijsbeer komen.

Daarvoor is het eerst van belang te weten hoe de voedselketen met de ijsbeer aan de top er uit ziet. We weten nu dat PCB's zich vanuit het water ophopen via algen, diatomeeën, kleine waterkreeftjes, vissen en zeehonden (Figuur 1). Die laatste stond vooral op het menu van de ijsbeer

Ik heb in de jaren tachtig en negentig van de vorige eeuw zelf, met verschillende studenten, promovendi en collega's veel onderzoek gedaan naar bioaccumulatie, m.n. in algen en vissen (Sijm, 1992; Sijm et al., 1992; Sijm et al., 1995a). Met gegevens van andere onderzoekers vonden we kwantitatieve cijfers over die ophoping van PCB's in algen en vissen en dat door de voedselketen heen die concentraties steeds hoger worden. In de algen vindt een concentratiestap van zo'n 10.000 plaats en met iedere stap in de voedselketen gaat dat met een extra factor van 3 of 5 , tot dat getal van ruim 10 miljoen in de ijsbeer. 


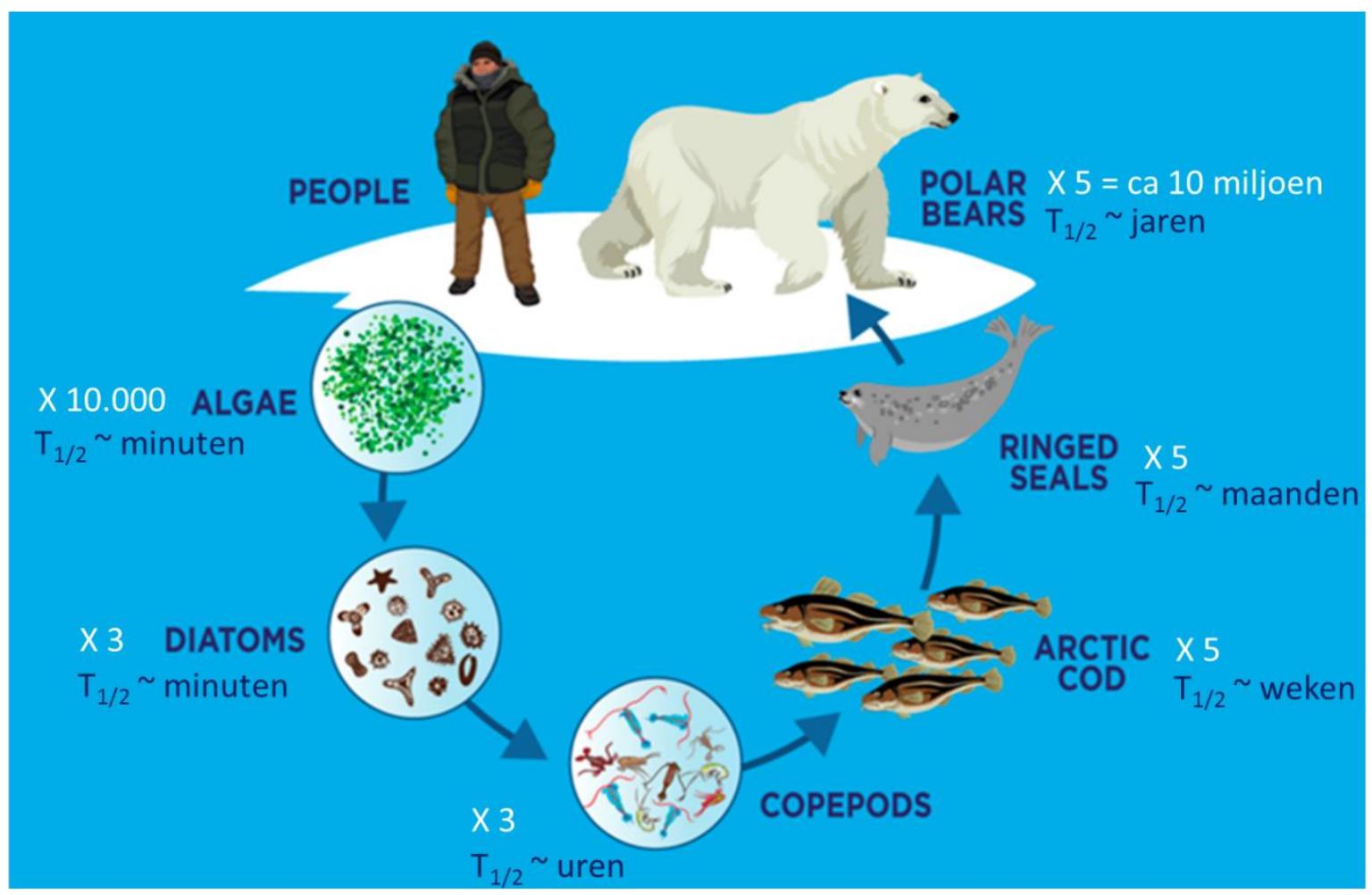

Figuur 1. De voedselketen van de ijsbeer, met daarbij de bioaccumulatiefactoren en halfwaardetijden (T1/2) van de PCB's in de verschillende organismen. Afbeelding aangepast van: https://polarbearsinternational.org/news/article-research/pollution-in-polar-bears/

Belangrijk hierbij is ook de snelheid waarmee die PCB's kunnen verdwijnen uit de organismen, als ze weer in een schone omgeving komen, hier uitgedrukt in de halfwaardetijd $t \frac{1}{2}$. Die blijkt sterk afhankelijk te zijn van de grootte van het organisme en van zijn vetgehalte. Zo duurt het enkele minuten tot uren voordat algen die PCB's weer kwijtraken, voor de waterkreeftjes enkele uren, voor vissen enkele weken tot maanden en voor de ijsberen en de mens duurt dat zelfs verschillende jaren!

De reden dat PCB's ophopen uit het water is thermodynamisch te verklaren, zoals de hier aanwezige professor Opperhuizen destijds heeft gedaan (Opperhuizen, 1986). Het gaat simpelweg om een verdelingsproces: PCB's zijn hydrofobe stoffen die liever in het vetweefsel zitten van organismen dan in het water en verdelen zich daarom ten gunste van het organisme. Wat initieel moeilijker te begrijpen was, is waarom verderop in de voedselketen die concentraties nog meer oplopen. Onderzoek van Gobas gaf die verklaring: door én opname van voedsel en afname van het vetgehalte in het voedsel tijdens de vertering, kon dat worden verklaard (Gobas et al., 1999).

\section{Voedingsadviezen}

We weten nu dus hoe die PCB's in de voedselketen en in de ijsbeer terechtkomen. We weten ook dat die PCB's nadelige effecten veroorzaken. Hoewel die PCB's inmiddels zijn verboden, zijn ze nog volop aanwezig in het milieu. Voorlopig kunnen we die PCB's dus niet vermijden! Wat we dan nog wél kunnen doen is een voedseladvies geven. Zo was ik afgelopen zomer met mijn familie op vakantie in de Verenigde Staten en zag aan de rand van de baai van San Francisco een bord staan met daarop in 3 talen dat vrouwen tussen de 18 en 45 én jonge kinderen beter sommige vissen niet en andere vissen wel mogen eten. Dit vanwege de hoge gehaltes aan PCB's en kwik in die vissen. Dit is dus in de VS anno 2019 en niet op de Noordpool en niet in de jaren '80 en '90 van de vorige eeuw! Dat advies wordt dus gegeven om vrouwen in hun vruchtbare periode geen vis te laten eten met teveel PCB's, om hun baby's te beschermen!

Dichterbij, in Nederland krijgt de Nederlandse bevolking ook voedingsadviezen, namelijk van het Voedingscentrum. Die kent een vergelijkbaar verhaal, namelijk dat zwangere vrouwen beter geen (vette) paling kunnen eten en als ze toch vis willen eten, beter 
andere soorten kunnen consumeren (zie: https://www.voedingscentrum.nl).

Hoe komen de PCB's op de Noordpool? Voor deze vraag te beantwoorden is het eerst goed om te weten waarvoor PCB's werden gebruikt.

PCB's werden tot de jaren '70 van de vorige eeuw gebruikt in transformatoren en verf (Mackay et al., 2006). Die PCB's bleken langzaam te verdampen naar de lucht en vervolgens door de wind naar andere delen van de wereld getransporteerd. Hier was geen sprake van rokende schoorstenen uit die transformatoren of vanaf de ramen van huizen. Integendeel, het gaat om onzichtbare processen, waarbij minuscule hoeveelheden per dag verdampen!

Temperatuur speelt hierbij een grote rol voor stoffen die zich via de lucht bewegen, zij springen als het ware door de seizoenen heen als sprinkhanen van warmere naar koudere regionen. PCB's die in de zomer vanuit de bodem weer verdampen komen weer in de lucht, slaan in de winter weer neer in een bodem meer noordelijk en verplaatsen zich zo langzamerhand naar de polen (Figuur 2). Dit wordt dan ook het 'grasshopper'- of 'sprinkhaan'-effect genoemd (Gouina et al., 2004).

Globaal gaat die verdeling mee met de grote bewegingen van lucht en water. PCB's verdelen zich dus over de verschillende milieucompartimenten: water, lucht, onderwaterbodem, bodem en levende organismen. De $\mathrm{PCB}^{\prime}$ s gingen dus niet in één keer naar de Noordpool, maar verdeelden zich vanuit de lucht naar water en bodem. Ook in het water verdeelden die PCB's zich vervolgens weer over de onderwaterbodem en over levende dieren, zoals vissen en algen, zoals we zojuist hebben gezien. In de bodem hopen PCB's zich ook op in de voedselketen.

De milieuchemie gaat dus over 3 V's: de eerdergenoemde verplaatsing en verdeling en ook over verandering.

Bij veranderen gaat het om de chemische reacties die in het milieu én in levende organismen kunnen plaatsvinden. PCB's zijn echter stoffen die bijna geen reacties ondergaan en dus niet snel veranderen. Andere stoffen ondergaan die wel, en kunnen bijvoorbeeld onder invloed van zonlicht veranderen. Dit wordt fotolyse genoemd. Andere veranderingen, zoals hydrolyse of oxidatie- en reductiereacties vinden plaats in water, in de bodem en in onderwaterbodem. Biodegradatie, de omzetting door microorganismen of bacteriën, is heel belangrijk voor veranderingen van chemische stoffen. Tenslotte kunnen chemische stoffen ook door andere levende wezens, zoals vissen of zoogdieren, worden omgezet. Dat wordt biotransformatie genoemd. Ik heb hieraan een groot deel van mijn promotie-onderzoek besteed (Sijm, 1992).

$\mathrm{Er}$ is in de laatste decennia al veel onderzoek gedaan naar die verschillende milieuchemische processen van verplaatsen, verdelen en veranderen van PCB's. We hebben hierbij te maken hebben met meer dan PCB's alleen. Er zijn meer dan 150.000 verschillende geregistreerde chemische stoffen in Europa $\left(E C H A^{1}\right)$. Sommige van die stoffen bestaan weer uit vele duizenden individuele chemische stoffen, zoals aardoliedestillaten, ze komen voor in miljoenen (consumenten)producten en verplaatsen en verdelen zich over de hele wereld.

Het is dus onbegonnen werk om al die individuele stoffen apart te gaan onderzoeken. De uitdaging is dan ook om meer fundamenteel te begrijpen welke eigenschappen van de chemische stoffen in combinatie met de eigenschappen van het milieu, die verplaatsing, verdeling en verandering bepalen.

Professor Don Mackay is een van de eersten geweest, die de verdeling en verplaatsing van chemische stoffen goed heeft onderzocht en daar niet alleen modellen (Mackay, 2001) voor heeft ontwikkeld, maar ook in een aantal handboeken die eigenschappen van verschillende klassen van chemische stoffen systematisch op een rijtje gezet (bijvoorbeeld: Mackay et al., 2006).

Professor René Schwarzenbach is een andere belangrijke milieuchemicus die niet alleen die eigenschappen van chemische stoffen heeft beschreven die belangrijk zijn voor verplaatsing en verdeling, maar ook de chemische reacties beschreven die tot verandering van chemische stoffen kunnen leiden (Schwarzenbach et al., 2002).

\footnotetext{
${ }^{1}$ https://echa.europa.eu/nl/
} 


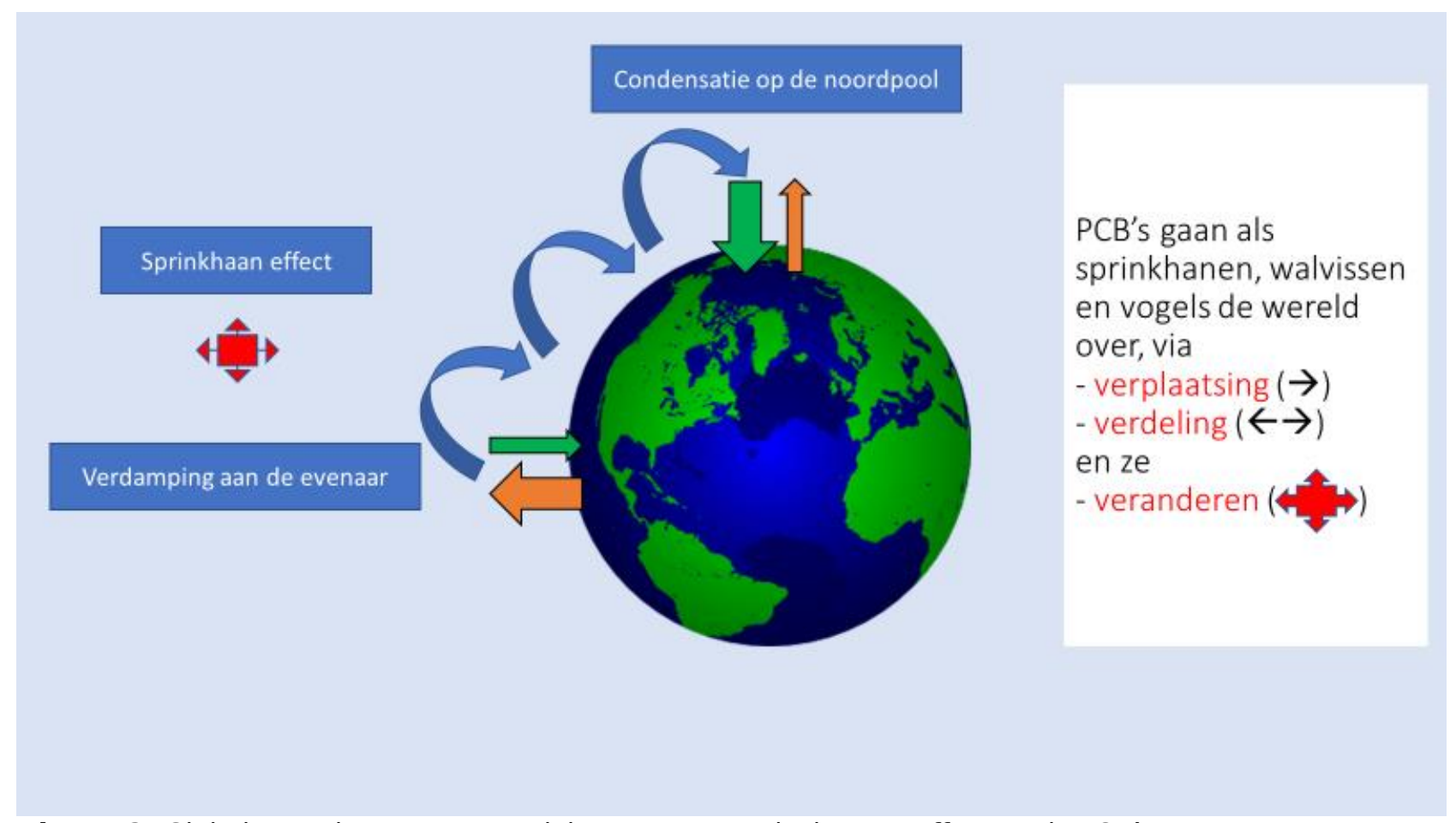

Figuur 2. Globale verplaatsing en verdeling van semi-vluchtige stoffen, zoals PCB's van warmere regionen op de aarde naar de polen door afwisselende verdamping en condensatiestappen, ook wel het sprinkhaan-effect genoemd. Daarnaast kunnen PCB's door verschillende type reacties ook veranderen.

\section{Welke lessen hebben we tot nu toe geleerd?}

Een deel van deze lessen staan opgetekend in mijn proefschrift (Sijm, 1992). Zo weten we het volgende over PCB's en vergelijkbare, hydrofobe stoffen, die semi-vluchtig zijn:

- $\quad$ Bioaccumulatie $=$ verdeling, afhankelijk van

$$
\begin{array}{ll}
\circ & \text { groei } \\
\circ & \text { voortplanting } \\
\circ & \text { dier (gewicht, vetgehalte) } \\
\circ & \text { stof (molekuulgewicht, } \\
& \text { octanol-water } \\
& \text { verdelingscoëfficient [Kow] } \\
& \text { en Henry's Law constante } \\
& [\mathrm{He}])
\end{array}
$$

- Milieugedrag (= o.a. verplaatsen en verdelen)

$$
\text { - redelijk makkelijk te }
$$
voorspellen

- $\quad$ Biotransformatie = verandering

- afhankelijk van het organisme (enzymen)

- verlaagt bioaccumulatie

- beïnvloedt toxiciteit

- moeilijk te voorspellen (dit is ook de conclusie van Sijm et al., 1997)

Verder is duidelijk geworden van het PCBverhaal, dat slechts kleine hoeveelheden kunnen leiden tot effecten, die zich pas na vele jaren manifesteren en waarbij voedsel een belangrijke bron is van milieucontaminanten, zoals PCB's zijn.

Naast onderzoek aan de bioaccumulatie, biotransformatie en toxiciteit van PCB's in vissen en algen heb ik, samen met vele collega's, onderzoek gedaan naar verschillende andere chemische stofgroepen in verschillende aquatische, terrestrische- en benthische organismen (Opperhuizen \& Sijm, 1990; Belfroid et al., 1994; Sijm et al., 1995b; Sijm \& van der Linde, 1995; Belfroid et al., 1996; de Maagd et al., 1997; Legierse et al., 1998; Bakker et al., 1998; Tolls \& Sijm, 2000). Deze lessen over verplaatsen, verdelen en veranderen van chemische stoffen zijn opgetekend in een hoofdstuk (Sijm et al., 2007) in het boek: Risk Assessment of Chemicals: An Introduction, met Kees van Leeuwen en Theo Vermeire als redacteurs (Van Leeuwen \& Vermeire, 2007), dat is vertaald in het Chinees en daar door duizenden risicobeoordelaars van de overheid en de chemische industrie wordt gebruikt voor de risicobeoordeling van chemische stoffen.

Betekent dit nu dat we verplaatsing, verdeling en verandering van álle stoffen goed begrijpen? Helaas nog niet. Er is nog veel te onderzoeken! 


\section{Risicobeoordeling}

De mens wordt dus dagelijks aan vele duizenden chemische stoffen blootgesteld, via voedsel, water en lucht. De meesten van u zullen dat niet dagelijks ervaren en dat is misschien maar goed ook. We willen wel graag weten of die chemische stoffen wel of geen kwaad kunnen.

Voor de inschatting van het risico is enerzijds informatie nodig over de verplaatsing, verdeling en verandering, zoals ik hiervoor heb toegelicht. Dat geheel bepaalt de blootstelling waaraan de mens via lucht, water en voedsel wordt blootgesteld. Anderzijds is het belangrijk om te weten hoe gevaarlijk die chemische stoffen zijn.

Zo geldt voor iedere chemische stof dat die nadelige, toxicologische effecten kan veroorzaken, afhankelijk van de mate van de blootstelling. Belangrijk is dan te weten welke nadelige effecten dat zijn, voor wie die effecten nadelig zijn en bij welk blootstellingsniveau die effecten zich voordoen. Nadelige effecten kunnen dus variëren van lichte irritatie van de huid als de stof daar op komt, tot sterfte, tot effecten op onze nakomelingen, maar ook obesitas, verminderde vruchtbaarheid en ADHD worden wel in verband gebracht met blootstelling aan chemische stoffen.

\section{ADME}

Hierbij is het van belang te weten of die effecten optreden na opname in de longen, opname in of door de huid of opname door de mond en in welke mate dat gebeurt. Deze kennis gaat over Absorptie, de 'A' in ADME.

$\mathrm{Na}$ opname in het lichaam verspreidt de chemische stof zich over het lichaam. Dit gaat dus ook weer over verdeling en verplaatsing. Hierbij is het belangrijk om te weten of een stof zich verdeelt over vet of eiwitten of de botten en in welke organen, zoals de lever of de nieren, van het lichaam deze zich gaat verdelen.

Met name in de lever, maar ook in andere organen kunnen chemische door enzymen worden veranderd. Veelal worden die chemische stoffen op die wijze minder gevaarlijk en sneller uitgescheiden dan de oorspronkelijke stof. In een aantal gevallen worden stoffen echter toxischer dan de oorspronkelijke stof. Een bekend voorbeeld daarvan is benzo(a)pyreen, een van de meest kankerverwekkende PAK's (polycyclische aromatische koolwaterstoffen), die pas kankerverwekkend wordt als achtereenvolgens twee enzymen deze veranderen in de kankerverwekkende vorm.
Kennis over welke enzymen een mens beschikt, wat die enzymen doen en hoe die zich verhouden tot wat er in proefdieren is bekend, is dan zeer relevant voor de inschatting of chemische stoffen worden omgezet in andere stoffen.

Tenslotte zijn er verschillende manieren om van een chemische stof af te komen. Dit kan bijvoorbeeld door uitademen van stoffen, door uitzweten via de huid, met urine of ontlasting of door moedermelk naar de baby!

\section{Risicobeoordeling voedselveiligheid} Voor voedselveiligheid is opname via de mond de meest belangrijke route waarlangs chemische stoffen het lichaam van de mens binnenkomen. Dit geldt voor de consument. De werkers in de voedselindustrie kunnen echter ook via de longen en de huid worden blootgesteld aan deze chemische stoffen bij het bereiden van levensmiddelen.

Bij de risicobeoordeling van voedselveiligheid is het doel na te gaan of de chemische stoffen die in voedsel zitten veilig zijn of niet. $\mathrm{Bij}$ deze risicobeoordeling is het dus belangrijk om te weten wat de toxicologie is van de chemische stof en wat daarbij veilige grenzen of gezondheidskundige normen zijn. Maar ook om te weten in welke gehalten die chemische stoffen in het voedsel aanwezig zijn en hoeveel van dat voedsel door een consument wordt geconsumeerd.

Die risicobeoordeling levert 3 mogelijke uitkomsten op:

a) Er is geen risico;

b) $\mathrm{Er}$ is onvoldoende kennis, over de toxicologie en/of over de blootstelling, om de risicobeoordeling uit te voeren, of

c) $\mathrm{Er}$ is een risico.

Afhankelijk van de uitkomst zal de overheid of het bedrijfsleven dienen in te grijpen, zeker in geval er een risico is, en het gebruik van de stof moet worden beperkt of verboden.

\section{Voedselveiligheid en een duurzame economie}

De opgedane kennis van de milieuchemie, toxicologie en risicobeoordeling zijn dus belangrijke pijlers waarop mijn onderzoek naar voedselveiligheid in een duurzame economie rusten. Voor ik verder overga op voedselveiligheid zal ik nog even ingaan wat ik onder een duurzame economie versta. 


\section{Een duurzame economie}

Onze samenleving draait op wat de aarde ons geeft: we gebruiken de grondstoffen voor voedsel, onderdak, warmte, kleding, elektrische apparaten en mobiliteit. Die behoefte aan grondstoffen neemt alleen maar toe. In 2050 zijn er naar verwachting ruim negen miljard mensen die voldoende voedsel en water nodig hebben en in welvaart willen leven. Om dat mogelijk te maken is de circulaire economie nodig (TK, 2016). De SER (2016) ziet een circulaire economie als een economie die binnen ecologische randvoorwaarden efficiënt en maatschappelijk verantwoord omgaat met producten, materialen en hulpbronnen, zodat ook toekomstige generaties toegang tot materiële welvaart behouden.

De ambitie van het kabinet is om samen met maatschappelijke partners in 2030 een (tussen)doelstelling te realiseren van $50 \%$ minder gebruik van primaire grondstoffen (mineraal, fossiel en metalen). Met deze doelstelling op grondstoffengebruik sluit Nederland aan bij het ambitieniveau in vergelijkbare landen (TK, 2016). Het kabinet vindt het noodzakelijk om de reeds ingezette transitie van een lineaire- naar een circulaire economie te versnellen. Dit wordt onderschreven door de Sociaal Economische
Raad (SER, 2016) en de Raad voor de Leefomgeving en Infrastructuur (RLI, 2015).

Momenteel zijn er al veel initiatieven om afval om te zetten naar grondstoffen, om plastic, metaal en papier te recyclen, en om biomassa om te zetten naar bioplastics. Dit soort initiatieven draagt daarbij bij aan de mondiale doelstellingen over duurzame ontwikkeling (Sustainable Development Goals), zoals het streven naar halvering van de wereldwijde voedselverspilling, duurzame productie- en consumptiepatronen, armoedebestrijding, duurzaam gebruik van natuurlijk kapitaal en afvalreductie, en bijvoorbeeld de bestrijding van zwerfvuil op zee (de "plastic soup").

Volgens Milieucentraal produceren we in Nederland jaarlijks bijna 490 kilo afval per persoon. Ruim de helft daarvan leveren we gescheiden in. Papier en glas staan aan kop: daarvan brengen we ruim 70 procent naar de papierbak of glasbak ${ }^{2}$. Van het gft wordt bijna 60 procent gescheiden, plastic verpakkingen en drinkpakken zijn in opmars. Volgens een andere bron werd in 2016 85\% van het in Nederland gemaakte nieuw papier en karton gemaakt uit gerecycled oud papier en -karton, een hoeveelheid van circa 2.454.000 ton en een besparing van circa 7,5 miljoen bomen ${ }^{3}$.

\section{Lineaire economie}

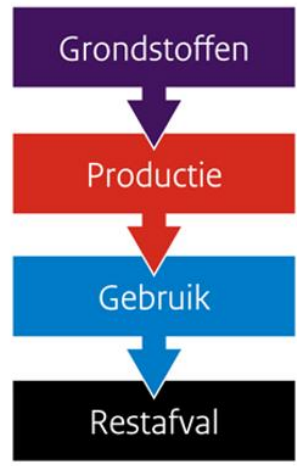

Economie met recycling

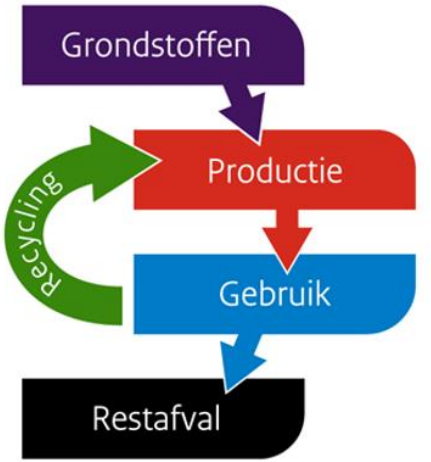

Circulaire economie

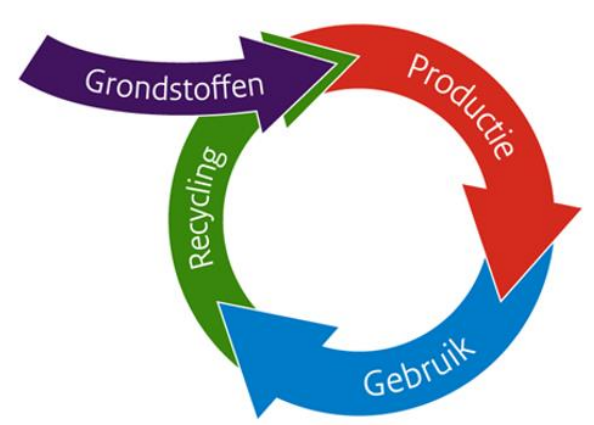

Figuur 3. Van de traditionele lineaire economie via een gedeeltelijke circulaire economie naar een volledige circulaire economie (https://www. rijksoverheid.nl/onderwerpen/circulaireeconomie/werking-circulaire-economie).

Ik ga nu in op twee ontwikkelingen rondom de duurzame economie in relatie tot voedselveiligheid: alternatieve eiwitbronnen en voedselverpakkingsmaterialen.

\footnotetext{
2 https://www.milieucentraal.nl/minderafval/afval-scheiden-cijfers-en-kilos/
}

\section{Alternatieve eiwitbronnen}

De eerste ontwikkeling rondom de duurzame economie gaat over het gebruik van alternatieve eiwitbronnen. Eiwitten van insecten, bonen, algen, zeewier, eendenkroos, gras en koolzaad zijn mogelijke

\footnotetext{
${ }^{3}$ https://papierenkarton.nl/duurzaamheidmvo/duurzaamheid/duurzaam-gebruik/recycling/
} 
nieuwe bronnen om aan voedingsmiddelen toe te voegen ${ }^{4}$. Die leiden al tot een veranderend winkelwagentje. De consumenten van nu of die van over 10 jaar zullen andere voedselbronnen consumeren dan die van nu of langer geleden!

Overigens mogen al deze nieuwe eiwitbronnen niet zomaar op de markt worden gebracht. Ze vallen namelijk onder de 'Novel Food' Verordening (EG nr. 258/97) voor nieuwe voedingsmiddelen en voedselingrediënten. Deze wet schrijft voor dat een Europese toelatingsprocedure moet worden doorlopen waarbij de veiligheid van de nieuwe eiwitten wordt beoordeeld voordat het eiwit op de markt wordt gebracht.

Daarvoor zijn niet alleen gegevens nodig over de samenstelling en voedingswaarde, maar ook over het beoogde gebruik en innamehoeveelheden, de concentraties van mogelijke contaminanten in het nieuwe eiwit, de microbiologische en toxicologische eigenschappen en de potentiële allergeniciteit (Van der Spiegel et al., 2013).

\section{Insecten}

Ik wil nu even inzoomen op de groeiende aandacht voor -de kweek van -insecten. Die zijn een belangrijke bron van eiwitten en hebben een laag vetgehalte. Insecten worden meer en meer ingezet als nieuwe eiwitbron, met name voor diervoeders, waarbij zij worden gekweekt op rest- en afvalstromen. Het idee is er zelfs om insecten op mest te gaan kweken, wat een deel van het mestprobleem zou oplossen!

Het ministerie van Landbouw, Natuur en Voedselkwaliteit (LNV) ziet grote kansen voor het gebruik van reststromen in de voedselketen, zoals voormalige voedingsmiddelen (VVM) ${ }^{5}$, als voedingsbodem (substraat) voor insecten. Insecten kunnen vervolgens worden gebruikt als grondstof voor diervoeder en zo bestemd voor voedselproducerende dieren. Het ministerie ondersteunt deze ontwikkeling mits deze geen risico's voor dier- en volksgezondheid met zich meebrengt (TK, 2013).

Kortom, bij de stimulering en verdere toename van hergebruik van (afval)stoffen

\footnotetext{
${ }^{4}$ https://www.wur.nl/nl/OnderzoekResultaten/OnderzoeksprojectenLNV/Expertisegebieden/kennisonline/Voedselveiligh eid-alternatieve-eiwitbronnen.htm

${ }^{5}$ Kamerbrief 13058527 . Stand van zaken betreffende insecten in diervoeder en aquacultuur. 19 april 2013.

${ }^{6}$ Levensmiddel of voedingsmiddel: 'alle stoffen en producten, verwerkt, gedeeltelijk verwerkt of onverwerkt, die bestemd zijn om door de mens te
}

en beter gebruik van biomassa, voedselresten en -afval dient aandacht te zijn voor de voedselveiligheid. Bureau

Risicobeoordeling \& onderzoek (BuRO) van de Nederlandse Voedsel- en Warenautoriteit (NVWA) heeft al verschillende adviezen uitgebracht over de dier- en volksgezondheidsrisico's van insecten als grondstof voor diervoeder (BuRO, 2015; BuRO, 2019) en de consumptie van gekweekte insecten (BuRO, 2014; BuRO, 2016). Ook Van der Fels-Klerx et al. (2018) concluderen dat sommige zware metalen een voedselveiligheidskwestie kunnen zijn bij de kweek van insecten en behoeft de voedselveiligheid nog nader onderzoek.

Hierbij is ook van groot belang het risico voor de kwekers van insecten te onderkennen: er zijn al vele kwekers opgezadeld met soms zeer ernstige longproblemen door de allergische eigenschappen van insecteneiwitten (zie de adviezen van BuRO)!

\section{Voedselverpakkingsmaterialen}

De tweede ontwikkeling rondom de duurzame economie is die van voedselverpakkingsmaterialen.

Zoals al eerder gezegd wordt in Nederland $85 \%$ van het nieuwe papier en karton gemaakt uit gerecycled oud papier en karton, een hoeveelheid van circa 2.454.000 ton. Een deel van dat karton wordt als voedselverpakkingsmateriaal of voedselcontactmateriaal gebruikt. In een duurzame economie veranderen kranten, tijdschriften en plastics dus in voedselverpakkingen. Nederlanders verbruiken jaarlijks 26 miljard plastic voedselverpakkingen (NU.nl).

De belangrijkste Europese wet voor voedselcontactmaterialen is Verordening $1935 / 2004$. Sinds 2004 is deze Verordening van kracht en kent als algemene eisen dat voedselcontactmaterialen geen bestanddelen afgeven in hoeveelheden die de gezondheid kunnen schaden (artikel 3 lid a), geen onaanvaardbare wijziging in samenstelling kunnen veroorzaken (artikel 3 lid b), en geen aantasting van de organoleptische

worden geconsumeerd of waarvan redelijkerwijs kan worden verwacht dat zij door de mens worden geconsumeerd' (Verordening (EG) Nr. 178/2002 van het Europees Parlement en de Raad van 28 januari 2002 tot vaststelling van de algemene beginselen en voorschriften van de levensmiddelenwetgeving, tot oprichting van een Europese Autoriteit voor voedselveiligheid en tot vaststelling van procedures voor voedselveiligheidsaangelegenheden). 
eigenschappen kunnen veroorzaken (artikel 3 lid c).

Voor sommige voedselcontactmaterialen zijn specifieke richtlijnen en verordeningen, zoals voor kunststoffen (Verordening 10/2011), actieve en intelligente materialen (Verordening 450/2009), gerecyclede kunststoffen (Verordening 282/2008), keramiek (Richtlijn 84/500/EEG), en geregenereerde cellulosefolie (Richtlijn 2007/42/EG).

Voor alle voedselcontactmaterialen is een zogenaamde 'Declaration of Compliance' (DOC) of 'Verklaring van Overeenstemming' nodig om deze op de markt te kunnen brengen. Hiermee verklaart de fabrikant dat alle relevante wetgeving is nageleefd tijdens de productie van het materiaal.

Fabrikanten zijn verplicht om ervoor te zorgen dat kunststof

voedselcontactmaterialen geen hoge migratie vertonen (Artikel 9-12, Verordening 10/2011). In Bijlage III van Verordening $10 / 2011$ staan enkele simulanten omschreven die de eigenschappen van verschillende levensmiddelen kunnen nabootsen, zoals ethanol voor waterige oplossingen, azijnzuur voor zure oplossingen, ethanol voor alcoholische levensmiddelen, plantaardige olie voor vettige levensmiddelen, enz.

Binnen de Europese Unie bestaan er echter grote verschillen hoe voedselcontactmaterialen zijn gereguleerd. Frankrijk en Nederland hebben wetgeving op (vrijwel) alle niet-geharmoniseerde voedselcontactmaterialen, andere landen hebben hier (vrijwel) geen extra bepalingen voor (Van der Linden, 2018).

In de Nederlandse Warenwet staat dat verpakkingen geen stoffen in zodanige hoeveelheden aan voedsel en dranken mogen afgeven dat ze gevaarlijk zijn voor de gezondheid. In zowel de Nederlandse als de Europese wetgeving is voor niet-gereguleerde stoffen een globale migratielimiet van 60 $\mathrm{mg} / \mathrm{kg}$ levensmiddel vastgesteld.

Bij kringlooppapier wordt gecontroleerd of het schoon genoeg is om weer voedingsmiddelen in te verpakken. Voor kunststofrecycling gelden ook strenge regels: alle stoffen in het kunststof moeten op een positieve lijst staan. Daarnaast moet het recycleproces zijn goedgekeurd, waarvoor de
Europese Voedselveiligheid Autoriteit (EFSA) verantwoordelijk is.

Veel kunststof verpakkingen voor voedsel bevatten vanwege deze hygiëneregels (nog) geen gerecycled kunststof. Bij het verpakken van andere producten dan voeding, spelen voedselveiligheidseisen geen rol en kan meer gerecycled materiaal gebruikt worden. ${ }^{7}$

De supermarktketen Plus heeft zelf besloten te stoppen met het gebruik van zwarte kunststof verpakkingen omdat deze in de praktijk niet zijn te recyclen.

\section{Mogelijke chemische risico's van gerecyclede \\ voedselverpakkingsmaterialen?}

Een risico wordt, zoals eerder uitgelegd, ingeschat als we weten om welk gevaar het gaat, of we daarvan de toxiciteit kennen en of we de blootstelling ervan kennen.

In voedselverpakkingsmaterialen van papier en karton zijn inmiddels meer dan 8000 chemische stoffen aangetroffen. Hiervan weten we van het merendeel niet eens wat van de toxicologische effecten (Van Bossuyt et al., 2016) en weten we ook niet hoeveel ervan naar het voedsel kan migreren. Onder die vele duizenden stoffen zitten in ieder geval een aantal die negatieve effecten hebben op de mens over een hele lange termijn, waarvan sommigen ook impact kunnen hebben op het nageslacht of medeverantwoordelijk worden geacht voor een verminderd immuunsysteem, ADHD en diabetes.

Niels van der Linden (2018), een student van de Universiteit van Wageningen, die bij de NVWA zijn stage deed, vond in de literatuur 194 individuele chemische stoffen in drie verschillende voedselcontactmaterialen, namelijk 28 in kunststoffen, 113 in papier \& karton en 64 in kleefstoffen. 111 van die stoffen zijn als gevaarlijke stof aangeduid. Hiervan worden er 85 nog niet gereguleerd door Nederlandse of Europese wetgeving en sommige stoffen zijn zelfs reeds expliciet verboden voor bepaalde levensmiddelen.

De Europese en Nederlandse wet- en regelgeving is dus niet toereikend om dit adequaat af te dekken en bovendien is binnen de wetgeving nog een mogelijkheid dat gerecyclede stromen deels onbeoordeeld toegelaten worden. Zo is er de mogelijkheid

\footnotetext{
${ }^{7}$ https://meldpuntverpakkingen.nl/veel-gesteldevragen/919/welke-grens-zit-er-aan-het-gehaltegerecycled-materiaal-van-verpakkingen.html
} 
bij door EFSA goedgekeurde processen om kunststof te recyclen met maximaal 5\% nonfood kunststof. Een andere risico is het gebruik van gerecyclede producten van buiten Nederland, waardoor stoffen die niet toegelaten zijn in Europa of Nederland, in voedselverpakkingsmaterialen en voedsel kunnen komen.

Inmiddels heeft het Europees Parlement ook zijn zorgen geuit en de Europese Commissie gevraagd de wetgeving rondom voedselverpakkingen te gaan herzien. Daar zijn inmiddels de eerste stappen voor gezet, namelijk het in kaart brengen wat de problemen zijn. Het zal dus nog wel enkele jaren duren voordat er nieuwe, scherpere wetgeving is. Ondertussen is er grote behoefte aan kennis rondom de veiligheid van die voedselverpakkingsmaterialen.

\section{Migratie}

Een aantal gevaarlijke stoffen komen vanuit papier en karton, kunststoffen, drukinkten, en kleefstoffen in levensmiddelen. Zo worden bijvoorbeeld papier of karton behandeld met een deklaag van PFAS, zoals PFOA om het materiaal waterdicht te krijgen, of wordt er zetmeel aan toegevoegd om het extra waterabsorptiecapaciteit te geven. Aan kunststofverpakkingen worden verschillende chemische stoffen toegevoegd om de elasticiteit te verhogen, kleur te geven, brandbaarheid te weren, of te stabiliseren tegen UV-straling en oxidatie. Soms worden er ook biociden toegevoegd of vulstoffen en verstevigers. Al die verschillende soorten chemische stoffen zouden mogelijk kunnen migreren van de voedselverpakking naar het voedsel.

Verpakkingen worden ook meestal voorzien van tekst en een etiket. Hierbij worden drukinkten gebruikt om de consument te voorzien van informatie over het product, een wettelijke eis vanuit Verordening 1169/2011. Hoewel de traditionele inkten gemaakt van olie of harsen nog steeds veel gebruikt worden, wordt er ook steeds meer gebruikgemaakt van inkten die uitharden onder invloed van UV of elektronenstralen, en daardoor minder migratie vertonen. Vanuit de wettelijke eis mag alleen de niet-bedrukte kant in contact staan met het voedsel, en moet tussen voedsel en inkt een zogenaamde functionele barrière staan die migratie beperkt. Jaarlijks wordt ongeveer 400.000 ton aan inkt geproduceerd binnen de Europese Unie bedoeld voor voedselcontactmaterialen. Alleen Frankrijk, Nederland, Kroatië, Tsjechië, Duitsland, Italië, Slowakije, en Zwitserland kennen binnen Europa regelgeving voor drukinkten, alhoewel er ook vanuit de Raad van Europa niet-wettelijke richtlijnen zijn.

Binnen de verschillende wetgevingen worden ongeveer 5200 stoffen benoemd. Het opvallende is echter dat hierbij vrijwel geen stoffen in de wetgeving van andere landen voorkomen; veel inkten zijn dus niet opgenomen op de lijsten van andere landen: slechts 34 van de 5214 stoffen worden door 3 of meer landen gereguleerd (Simoneau et al., 2016).

De gevaarlijke stoffen die van der Linden (2018) vond, kennen een grote variëteit aan chemische stoffen, die meer of minder goed zijn gedefinieerd, zoals gebromeerde vlamvertragers, minerale olie (MOSH en $\mathrm{MOAH}$ ), ftalaten, parabenen, fenolen, (fotoinitiatoren van) drukinkt, IAS (intentionally added substances) en NIAS (non-intentionally added substances), (zware) metalen, trichlooranisol, chloorhoudende verbindingen, monomeerresten, aldehyde, PFAS, PAK, BPA, DEHP, NMP, NDP en epoxyverbindingen. Hierbij is ook migratie van chemische stoffen gevonden door functionele barrières heen, uit kleefstoffen, naar vloeibaar en vast voedsel en is in een enkel geval ook genotoxiciteit aangetoond van de gemigreerde chemische stoffen. Van der Linden vond ook aanwijzingen dat kunststof uit elektronica vanuit gerecycled materiaal in voedselcontactmaterialen is gekomen (Puype et al., 2015).

De mogelijkheid om (gevaarlijke) stoffen aan te treffen in levensmiddelen komt doordat stoffen kunnen migreren vanuit de verpakking naar het voedsel. Stoffen migreren van het verpakkingsmateriaal zelfs via de lucht. Migratie is dus een vorm van verplaatsen van de chemische stof uit het voedselverpakkingsmateriaal naar het voedsel en een verdeling van die stof over het verpakkingsmateriaal en het voedsel en soms de lucht die daar om heen zit (Crank, 1975; Poças, 2018). Dit zijn dus vergelijkbare processen als de PCB's die zich van warmere regionen naar de polen verplaatsen, maar dan wel op een veel kleinere schaal.

De mate van de migratie hangt af van een aantal factoren zoals de temperatuur, het contactoppervlak tussen het verpakkingsmateriaal en het levensmiddel, de dikte van het materiaal, de concentratie van de stof, de verdeling van de stof binnen het materiaal, en tijd (Barnes et al., 2006). Migratie kan worden tegengegaan door de bovenstaande factoren te beïnvloeden. Zo kan bijvoorbeeld door middel van koeling de 
migratie vertraagd worden, en kan door middel van toevoeging van andere materialen de verdeling veranderd worden. Voor dit laatste is een bekend voorbeeld de laag aluminium bij drankpakken en chipszakken.

Door recycling zoals beschreven in het vorige hoofdstuk kunnen stoffen zowel uit vorig gebruik, als uit andere materialen in nieuw geproduceerd materiaal terecht komen. Hierdoor kan een extra bron van migratie ontstaan.

\section{Onderzoek naar de Foodture!}

Voor wat betreft de voedselveiligheid in een duurzame economie heb ik dus twee specifieke aandachtgebieden met daarin de focus op chemische veiligheid:

1. het gebruik van gerecyclede verpakkingsmaterialen, die (gevaarlijke) chemische stoffen kunnen overbrengen naar het voedsel en waardoor de voedselveiligheid in het geding komt en

2. het gebruik van nieuwe eiwitbronnen, waar enerzijds bij de productie de veiligheid van de productiewerkers en anderzijds bij de consumptie voedselveiligheidsproblemen kunnen spelen.

Het gaat hier om een enorme ambitieuze opgave. Immers, het gaat om vele chemische stoffen in vele verpakkingsmaterialen en vele soorten (nieuwe) levensmiddelen. De hoofdvraag is dan of dit alles tot veilig voedsel leidt?

\section{Voedselverpakkingsmaterialen}

Zoals al eerder gezegd kennen we inmiddels duizenden chemische stoffen in voedselverpakkingsmaterialen, waar we van het merendeel niet eens weten wat de toxicologische effecten zijn noch hoeveel ervan naar het voedsel migreert.

\section{Nieuw voedsel}

Bij nieuwe of andere opkomende voedselbronnen is het vanuit chemische voedselveiligheid vooral van belang te weten onder welke omstandigheden dat voedsel is opgegroeid of gemaakt. Denk hierbij aan de substraten van gekweekte insecten, maar ook aan de milieucondities waarin algen en zeewier opgroeien, en aan de productieomstandigheden waarin werknemers worden blootgesteld.

Een eerste inzicht in een meer systematisch onderzoek naar de migratie is het in kaart brengen welke chemische stoffen migreren vanuit voedselverpakkingsmaterialen en terechtkomen in welke type levensmiddelen. Door dit systematisch te onderzoeken zal meer inzicht worden verkregen welk type levensmiddel / chemische stof-combinatie kan leiden tot migratie van de stof van het verpakkingsmateriaal naar het levensmiddel. Voor het onderzoek naar de verspreiding van chemische stoffen vanuit

voedselverpakkingen naar voedsel is het zaak daar zowel vanuit de chemie als de toxicologie naar te kijken.

De processen die hier achter zitten, zijn vergelijkbaar met de eerder genoemde milieuchemische processen die op globale schaal een rol spelen. De verplaatsing van chemische stoffen uit verpakkingsmaterialen zal namelijk ook verlopen via diffusie, via verdamping en afhankelijk van de verdeling tot bepaalde concentraties in het levensmiddel leiden.

Dit alles dient tot een betere inschatting van de voedselveiligheid voorafgaande aan marktintroductie van (nieuwe) voedseltypes en gedurende de recycling van oude materialen tot hernieuwde voedselverpakkingen of de verwerking van afval- en reststromen tot voedsel (zoals bij insecten).

\section{Welke chemische stoffen?}

Veel chemische stoffen zijn gereguleerd en daarvan is op zijn minst enige kennis over de toxicologie. Een aantal chemische stoffen worden verdacht van hun negatieve effecten na veel maanden of jaren aan blootstelling aan kleine hoeveelheden. Het kost bijvoorbeeld 10-20 jaar voordat het gehalte aan perfluorverbindingen in de mens een evenwicht, of beter steady-state niveau, bereikt. Als gedurende die periode een gezondheidskundige grens wordt overschreden kan het dus jaren duren voordat die effecten zich manifesteren.

Ik vind het dus belangrijk om na te gaan welke chemische stoffen, die uit voedselverpakkingsmaterialen of uit voedsel of diervoeder komen, op langere termijn mogelijk tot negatieve gezondheidskundige effecten leiden. Deze kennis kan dan helpen de risico's te beheersen van dit soort stoffen. Omdat het over zoveel verschillende chemische stoffen gaat, met verschillende mogelijke negatieve effecten op de gezondheid en die stoffen in vele voedselverpakkingsmaterialen voorkomen, is de uitdaging om (meer) systematisch onderzoek te doen naar de migratie uit en de toxicologische effecten van chemische stoffen in voedselverpakkingsmaterialen. Ik wil 
hierbij gebruik maken van de kennis van de milieuchemie en toxicologie, die ik hiervoor kort heb laten zien.

\section{Onderzoek en onderwijs?}

Mijn onderzoek en onderwijs zal zich dus richten op de risicobeoordeling van chemische stoffen in 'nieuw' voedsel en in gerecyclede voedselverpakkingen in een duurzame economie, met aandacht voor de consument en de werker. Hiervoor zal ik met bestaande samenwerkingsverbanden, zoals de Nederlandse Voedsel- en Warenautoriteit (NVWA), Wageningen Food Safety Research (WFSR), het Rijksinstituut voor Volksgezondheid en Milieu (RIVM) en nieuwe samenwerkingen een bijdrage leveren aan de voedselveiligheid.

\section{ER ZIT MEER ACHTER HET ETIKET}

Ik hoop dat het inmiddels duidelijk is waar de titel van mijn oratie over gaat. Het etiket van levensmiddelen bevat een aantal verplichte elementen, zoals de voedingswaarde en de hoeveelheden vetten, koolhydraten, eiwitten, vitamines, E-nummers, etc. Wat niet op het etiket staat en wat soms letterlijk achter het etiket of zelfs onderdeel is van het etiket, zijn de verpakkingsmaterialen en de chemische stoffen die er in zitten, die kunnen migreren naar het levensmiddel. Evenmin staat er op het etiket wat er aan chemische stoffen in het levensmiddel zit. Dit wordt steeds belangrijker om te weten, of beter nog, om te voorkomen, bij een toenemend gebruik van gerecycled materiaal en ook bij nieuwe vormen van levensmiddelen, zoals insecten en zeewier. Ik wil daar graag achter komen en richt me met onderzoek en onderwijs op de te ontwikkelen kennis en besef ten behoeve van de belangrijke maatschappelijke waarde van voedselveiligheid.

\section{Afsluitend}

Ik begon met het verhaal van de ijsbeer uit de jaren '70 en '80 van de vorige eeuw, die via zijn voedsel ongewild allerlei chemische stoffen binnenkreeg. Die ijsbeer verdiende veilig voedsel, net als de mens. Inmiddels is door het smelten van het poolijs en het terugdringen van de ijskap, de ijsbeer op zoek gegaan naar alternatieve eiwitbronnen. $\mathrm{Hij}$ eet nu de voedselresten van de mens uit afvalbakken en komt dus, net als de mens, ook in aanraking met voedselcontactmaterialen. Het is dus niet alleen voor de mens dat veilig voedsel en veilig voedselverpakkingsmateriaal en veilige voedselalternatieven van belang is, dit geldt evenzo voor de ijsbeer.

\section{Dankwoord}

Ik wil graag allereerst professor Antoon Opperhuizen bedanken die me wéér enthousiast heeft gemaakt: eerst al zo'n 33 jaar terug om een promotie-onderzoek te gaan doen en recent om deze leerstoel. Professor Willem Seinen wil ik bedanken voor zijn steun tijdens en na mijn promotieonderzoek.

De Universiteit Maastricht wil ik bedanken die me de gelegenheid geeft met energieke jonge collega's en collega's die jong-van-geest zijn, zoals professor dr Aalt Bast, te mogen werken aan voedselveiligheid.

Ik bedank de rector magnificus professor Rianne Letschert, en met haar het College van Bestuur, hartelijk voor het aanbieden van dit ambt en het vertrouwen in mij.

De collega's van de University College Venlo wil ik bedanken dat ze mij, één dag per week, gastvrij ontvangen en met wie ik over hun interessante onderzoeken mee mag praten en mijn verhalen mag presenteren.

Ik wil de Nederlandse Voedsel en Warenautoriteit hartelijk danken voor hun vertrouwen in mij en de steun voor mijn leerstoel.

Tenslotte wil ik mijn gezin: Trudie, Marcella en Berend bedanken om me altijd met de benen op de grond te laten staan.

Ik heb gezegd 


\section{Referenties}

- Bakker MI, Baas WJ, Sijm DTHM, Kollöffel C (1998). Leaf wax of Lactuca sativa and Plantago major. Phytochemistry 47, 1489-1493.

- Barnes K, Sinclair R, Watson D (2006). Chemical migration and food contact materials, Woodhead Publishing. ISBN: 9781845690298

- Belfroid A, Meiling J, Sijm D, Hermens J, Seinen W, van Gestel K (1994). Uptake of hydrophobic halogenated aromatic hydrocarbons from food by earthworms (Eisenia andrei). Arch. Environ. Contam. Toxicol. 27, 260-265.

- Belfroid AC, Sijm DTHM, van Gestel CAM (1996). Bioavailability and toxicokinetics of hydro-phobic aromatic compounds in benthic and terrestrial invertebrates. Environ. Rev. 4, 276-299.

- Bernhoft A, Wiig O, Skaare JU (1997). Organochlorines in polar bears (Ursus maritimus) at Svalbard. Environmental Pollution, 95, 159-175.

- BuRO (2014). Advies over de risico's van consumptie van gekweekte insecten.

Bureau Risicobeoordeling \& onderzoeksprogrammering. NVWA/BuRO/2014/2372, 15 oktober 2014.

- BuRO (2015). Risico's van het gebruik van categorie 2-materiaal van pluimvee voor de voeding van pelsdieren en gezelschapsdieren. Bureau Risicobeoordeling \& onderzoeksprogrammering. NVWA/BuRO/2015/5602, 1-10-2015.

- BuRO (2016). Positieflijst van voor productie te houden insecten. Bureau Risicobeoordeling \& onderzoeksprogrammering. NVWA/BuRO/2016/157, 25 augustus 2016.

- $\quad$ BuRO (2019). Advies over de dier- en volksgezondheidsrisico's van op voormalige voedingsmiddelen gekweekte insecten als grondstof voor diervoeder. Bureau Risicobeoordeling \& onderzoek. trcnvwa/2019/6200, 16 oktober 2019. Crank J (1975). The mathematics of diffusion. 2nd Edition, Clarendon Press, London. ISBN-10: 0198533446, ISBN13: 9780198533443

- de Maagd PGJ, van de Klundert ICM, van Wezel AP, Opperhuizen A, Sijm DTHM (1997). Lipid content and time-to-deathdependent lethal body burdens of naphthalene and 1,2,4-trichlorobenzene in fathead minnow (Pimephales promelas). Ecotoxicol. Environ. Saf. 38, 232-237.

- Gobas FAPC, Wilcockson JB, Russell RW, Haffner GD (1999). Mechanism of biomagnification in fish under laboratory and field conditions. Environ. Sci. Technol. 33, 133-141. https://doi.org/10.1021/es980681m

- Gouina T, Mackay D, Jones KC, Harner T, Meijer SN (2004). Evidence for the "grasshopper" effect and fractionation during long-range atmospheric transport of organic contaminants. Environmental Pollution, 128, 139-148.

- Hutzinger O. Editor. The Handbook of Environmental Chemistry. SpringerVerlag.

- Legierse KCHM, Sijm DTHM, van Leeuwen CJ, Seinen W, Hermens JLM (1998). Bioconcentration kinetics of chlorobenzenes and the organophosphorus pesticide chlorthion in the pond snail Lymnae stagnalis - a comparison with the guppy Poecilia reticulata. Aquat. Toxicol. 41, 301-323.

- Mackay D (2001). Multimedia Environmental Models: The Fugacity Approach, Second Edition. CRC Press.

- Mackay D, Shiu WY, Ma KC, Lee SC (2006). Handbook of Physical-Chemical Properties and Environmental Fate for Organic Chemicals. Volume 1. Introduction and Hydrocarbons. 2nd Edition, CRC Press.

- Opperhuizen A (1986). Bioconcentration in fish and other distribution processes of hydrophobic chemicals in aqueous environments. Proefschrift, Universiteit van Amsterdam.

- Opperhuizen A, Sijm DTHM (1990). Bioaccumulation and biotransformation of polychlorinated dibenzo-p-dioxins and dibenzofurans in fish. Environ. Toxicol. Chem. 9, 175-186.

Poças $F$ (2018). Migration from packaging and food contact materials into foods. Elsevier Inc. DOI: 10.1016/B978-0-08100596-5.21460-1

- Puype F, Samsonek J, Knoop J, Egelkraut-Holtus M, Ortlieb M. (2015). Evidence of waste electrical and electronic equipment (WEEE) relevant substances in polymeric food-contact articles sold on the European market. Food Additives \& Contaminants: Part A, 32(3), 410-426. 
- RLI (2015). Circulaire economie: van wens naar uitvoering. Raad voor de Leefomgeving en Infrastructuur.

- Schwarzenbach RP, Gschwend PM, Imboden DM (2002). Environmental Organic Chemistry 2nd Edition. WileyInterscience; ISBN-10: 0471357502, ISBN-13: 978-0471357506.

- SER (2016). Werken aan een circulaire economie: geen tijd te verliezen. Sociaal Economische Raad

- Sijm DTHM (1992). Influence of biotransformation on bioaccumulation and toxicity of chlorinated organic compounds in fish. Proefschrift, Universiteit Utrecht.

- $\quad$ Sijm DTHM, Seinen W, Opperhuizen A (1992). Life-cycle study on biomagnification in fish. Environ. Sci. Technol. 26, 2162-2174.

- Sijm DTHM, van der Linde A (1995). Size-dependent bioconcentration kinetics of hydrophobic organic chemicals in fish based on diffusive mass transfer and allometric relationships. Environ. Sci. Technol. 29, 2769-2777.

- Sijm DTHM, Middelkoop J, Vrisekoop K (1995a). Algal density dependent bioconcentration factors of hydrophobic chemicals. Chemosphere 31, 4001-4012.

- Sijm DTHM, Verberne ME, de Jonge WJ, Pärt P, Opperhuizen A (1995b). Allometry in the uptake of hydrophobic chemicals determined in vivo and in isolated perfused gills. Toxicol. Appl. Pharmacol. 131, 130-135.

- Sijm DTHM, de Bruijn J, de Voogt P, de Wolf W (1997). Biotransformation in environmental risk assessment. Proceedings of a SETAC-Europe Workshop, held in Noordwijkerhout, 28 april - 1 mei, SETAC-Europe, Brussels, Belgium, 1996.

- Sijm DTHM (2000). The 'B' in PBT: Bioaccumulation. In: Persistent, bioaccumulative, and toxic chemicals I. Fate and exposure. RL Lipnick, JLM Hermens, KC Jones and DCG Muir (Eds.), ACS Symposium Series 772, American Chemical Society, Washington, DC., pp. 13-26.

- Sijm D, Rikken M, Rorije E, Traas T, McLachlan M, Peijnenburg W (2007) Transport, Accumulation and Transformation Processes. In: Risk Assessment of Chemicals. (Eds. CJ van Leeuwen and $\mathrm{T}$ Vermeire). Springer, Dordrecht, The Netherlands, pp. 73-158.
- Simoneau C, Raffael B, Garbin S, Hoekstra E, Mieth A, Alberto Lopes JF, Reina V (2016). Non-harmonised food contact materials in the EU: regulatory and market situation. Ispra, Joint Research Center.

- Sonne C (2010). Health effects from long-range transported contaminants in Arctic top predators: An integrated review based on studies of polar bears and relevant model species. Environment International, 36, 461-491.

- TK (2013). Kamerbrief 13058527. Stand van zaken betreffende insecten in diervoeder en aquacultuur. Tweede Kamer, 19 april 2013.

- TK (2016). Tweede Kamer, vergaderjaar 2015-2016, 32 852, nr. 33. Brief van de Staatssecretaris van Infrastructuur en Milieu en de Minister van Economische Zaken aan de Voorzitter van de Tweede Kamer der Staten-Generaal Den Haag, 14 september 2016.

- Tolls J, Sijm DTHM (2000). Estimating the properties of surface-active chemicals. In: R.S. Boethling and D. Mackay, Handbook of property estimation methods for chemicals. Environmental and health sciences. Lewis Publishers, Boca Raton, FL, USA.

- Van Bossuyt $M$, van Hoeck E, Vanhaecke T, Rogiers V, Mertens B (2016). Printed paper and board food contact materials as a potential source of food contamination. Regulatory Toxicology and Pharmacology 81, 10-19.

- Van der Fels-Klerx HJ, Camenzuli L, Belluco S, Meijer N, Ricci A (2018). Food safety issues related to uses of insects for feeds and foods. Comprehensive Reviews in Food Science and Food Safety, 17, 1172-1183. https://doi.org/10.1111/15414337.12385|

- $\quad$ Van der Linden N (2018). Regulering rond risico. Voedselrisico's door recycling, en wetgeving in een circulaire economie. 850518-520-020. Afstudeeronderzoek voor de MSc Food Safety (Law), Wageningen University. Vakcode LAW70424.

- Van der Spiegel M, Noordam MY, Van der Fels-Klerx HJ (2013). Voedselveiligheid van nieuwe eiwitten. Voeding $\mathrm{Nu}, 3 / 4$, 14-15.

- Van Leeuwen CJ, Vermeire T (2007). Risk Assessment of Chemicals. (Eds.). Springer, Dordrecht, The Netherlands. 